\section{A qualitative study on vocational high school $12^{\text {th }}$ grade students' anxiety and expectations on university entrance exams ${ }^{1}$}

\section{Meslek lisesi 12. sinif öğrencilerinin üniversiteye giriş sınavı kaygıları ve beklentileri üzerine nitel bir çalışma}

\title{
Yeliz Temli Durmuş ${ }^{2}$
}

\begin{abstract}
This era could be named as "National and International Exams Era". Exams can be produced test anxiety and it affects physical, social, cognitive, behavioral and psychological conditions of a person. High expectations on exam's score, family's high expectations that above a student' cognitive talents, ineffective study styles and fear of being connected between IQ level of a student with the exam's score lead to anxiety. University entrance exams are perceived as the final exams in adolescence's life, which is the most important predictor of one's profession. In this qualitative study, semistructured interview question form was developed and in total of 30 vocational high school students enrolled in $12^{\text {th }}$ grade voluntarily participated in the study. One theme was emerged: Teachers' effect. Four categories were named as University entrance exams, Elementary school, Counseling, and Demands. Codes for first category are metaphors and time management. For Elementary school category one code was emerged: Lack of pre-requisite learning. The third category is named as Counseling Unit and it has three codes: Lack of psychological support, High expectations of families, and low expectations of teachers. The fourth category is Demands: Giving information
\end{abstract}

Özet

Yaşadığımız çağı "Sinavlar Çağı" olarak isimlendirebiliriz. Sinavlar bireylerde kaygiya neden olmakta, fiziksel, sosyal, bilişsel, davranısssal ve psikolojik durumunu etkilemektedir. Sınav sonuçlarıyla ilgili yüksek beklenti, ailelerin çocuklarının yeteneklerinin çok üstünde bilişsel yetenek sergilemelerini beklemeleri, etkisiz çalışma stilleri, zekâ seviyeleri sınav başarıları arasında bağlantı kuran insanların varlığ1 endişeye neden olmaktadır. Bir ergenin hayatında en önemli sinav, gelecekte mesleğini belirleyecek olan üniversiteye giriş sınavlarıdır. Bu nitel çalışmada yarı yapılandırılmış görüşme formu geliştirilmiş, toplam 30 onikinci sınıf meslek lisesi öğrencisi gönüllü olarak bu çalışmaya katılmıştır. Görüşmelerde elde edilen verilerin analizi sonucunda 1 tema ortaya çıkmıştır: Öğretmen etkisi. Dört kategori Üniversiteye giriş sınav1, İlköğretim, Psikolojik danışmanlık ve rehberlik birimi ve İstekler olarak isimlendirilmiştir. Metaforlar ve zaman yönetimi ilk kategoriyi oluşturan kodlardır. İlköğretim kategorisinde Temel bilgilerin olmaması kodu belirlenmiştir. Üçüncü kategori Psikolojik Danışma ve Rehberlik Birimi (pdr) kategorisinde üç kod belirlenmiştir: Bireysel psikolojik destek olmayışı, Ailelerin yüksek beklentisi ve

\footnotetext{
1 The study was partially presented in $1^{\text {st }}$ International Education Research and Teacher Education Congress, Uşak.

${ }^{2}$ Ph.D., Uşak University, Faculty of Education, Educational Sciences Department, yeliz.temlidurmus@,usak.edu.tr
} 
Temli Durmuş, Y. (2017). Meslek lisesi 12. Sınıf öğrencilerinin üniversiteye giriş sınavı kaygıları ve beklentileri üzerine nitel bir çalısma. Journal of Human Sciences, 14(4), 4826-4837. doi:10.14687/jhs.v14i4.5148

in the high school education process, and Needs for younger teachers. The results showed that various expectations exist from counseling department in a high school such as letting parents know the real cognitive skills of their child, providing open communication between teachers and students, offering vocational guidance starting from $9^{\text {th }}$ grade.

Keywords: Vocational high schools; university entrance exams; counseling; students' expectations; and anxiety.

(Extended English abstract is at the end of this document) öğretmenlerin düşük beklentisi ortaya çıkan kodlardır. Dördüncü kategori İstekler olarak isimlendirilmiş ve Süreçte bilinçlendirme ve Genç öğretmenlerin olması isteklerinin olduğu kodlar ortaya çıkmıştır. PDR servisinden çok farklı beklentilerin olduğu bu çalışmanın bulguları arasındadır. Ailelerin gerçekçi bir değerlendirme yetisi geliştirmelerine yardımc1 olmak, öğretmen ve öğrenciler arasında açık bir iletişim tarzı sağlamak ve 9. Sinıftan başlayarak mesleki rehberlik hizmeti sunulması beklentiler arasindadir.

Anahtar Sözcükler: Meslek liseleri; üniversiteye giriş sınavları; psikolojik danışmanlık ve rehberlik öğretmenleri; öğrenci beklentileri; kayg1.

\section{Giris}

Öğrenim göreceğimiz okulu belirleme, başarıyla diploma alabilme, bulunulan durumu koruma gibi isteklerimiz için sınavlar bir gereklilik olarak karşımıza çıkmaktadır. Hayatımızın bir parçası haline gelmekte olan sınavları göz önüne aldığımızda yaşadığımız çağ "sınav çağı" olarak isimlendirilebilir (Baybuğa, 2013). Türkiye'de genç nüfusun fazla olmasinın olumlu yanı insan kaynakları açısından zengin durumda olmak olarak değerlendirilebilir (Baştürk, 2011). Ancak bu durum daha iyi yaşamak ve beklentilerin karşılanması için insan kaynaklarının ortaya koyduğu yüksek potansiyelli yaşıtlarla yarış içinde olma durumunu ortaya çıkarır ve gençlerin akranlarından farklı ve özel yeteneklerini ortaya koyabilmelerini gerektirir (Dağlı, 2006). Her yaş grubunda yaşanabilecek sınav kaygısının fiziksel, zihinsel, davranışsal ve sosyal belirtileri mevcuttur (Yolcu, 2015). Kötü çalışma alışkanlıklanı, sınava ilişkin yüksek beklenti, zekâ düzeyinin sınav başarısıyla değerlendirileceği korkusu, ailelerin beklentilerine yanıt verememe sınava girecek ergenlerin olumsuz etkileyecek faktörler arasındadır (Donald, 2001, aktaran Şahin, Günay ve Bat, 2006). Gençlerin hayatında "dönüm noktası" olabilecek bir sınav gençlerde tedirginlik, kayg1 ve stres yaratmakta, zaten ergenlik döneminin getirdiği sorunlarla baş etme çabasındaki genç bireyin hissettiği olumsuz duygu durumlarını artırabilmektedir (Ekici, 2005). Merkezi sinavlarda kısa zaman aralıkları içerisinde değişikliğe gidilmesinin ve sınavların objektifliği hakkında endişe edilmesinin veli, öğrenci ve öğretmenlerin üzerinde yani toplumun büyük kesimin üzerinde olumsuz etki oluşturmaktadır (Can, 2010). Can (2017) ortaokuldan itibaren birçok merkezi sınava girildiğini belirmiştir. Çocukluk ve gençlik çağında da sınavların devam ettiği çıkarımının yapılabildiği çalışmasında bireylerin meslek gruplarına bağlı olarak birçok merkezi sınava girdiğinin altını çizilmiş (TUS, KPSS gibi) merkezî sistem sınavlarının birçok insanda olumsuz düşünce ve tutumlara neden olduğunu ortaya koymuştur.

İlkokuldan ortaokula geçiş döneminde birçok öğrenci için kaygı dönemi olarak isimlendirilebilir. Sosyal ve kişisel mesajları taşıyan bu süreç yaşamla başa çıkabilme-yaşama meydan okuma sürecidir (Jindal-Snape ve Miller, 2008). Riskli faktörler arasında tutarlı ve sürekli bir rehberlik hizmetinin olmaması, çalş̧malarda yetersiz performans sergilemek, iletişim problemleri, düşük özgüven bulunmaktadır (Pearce ve Holmes, 1994 akt. Jindal-Snape ve Miller, 2008). Eğitim programlarında başanı ve doğru ve eksiksiz uygulamalar için öğretmenlerle daha iyi iletişim kurabilme ve okulda sunulan eğitimin nitelikli olduğuna dair kuvvetli bir inanç etkili bulunmuştur (Lapan, Gysbers ve Petroski, 2001).

Bireylerin belki de bir ömür boyu yapacakları mesleklerini belirleyen üniversiteye giriş sınavları, sınav çağının belki de en önemli ve zorlayıcı sınavıdır (Şahin, Günay ve Batı, 2006). Genç 
Temli Durmuş, Y. (2017). Meslek lisesi 12. Sınıf öğrencilerinin üniversiteye giriş sınavı kaygıları ve beklentileri üzerine nitel bir çalısma. Journal of Human Sciences, 14(4), 4826-4837. doi:10.14687/jhs.v14i4.5148

bireylerin mesleklerini belirledikleri Üniversiteye giriş sınavları farklı biçimlerde uygulanmıştır. Adaylardan kayıt yapturmak istedikleri üniversite ve bölümlere ilişkin tercihlerin toplanmaya başladığ1 ve adayların aldıkları puanlarına ve tercihlerine göre merkezi olarak yerleştirildiği 1971 yıll, mezun olunan ortaöğretim kurumlarından diploma notlarının Ortaöğretim Başarı Puanı (OBP) adı altında belli ağırlıklarla sınav puanlarına yansıtılmaya başlandığ1 1982 yılı, yükseköğretim programları ile ilgili tercihlerinin sinava girmeden önce teslim edildiği ve adaylara tercihlerine göre belli test gruplarını cevaplama diğerlerini gözardı etme olanağının sağlandığı 1987 yılı, iki basamaklı sınavın ikinci basamağının kaldırıldığı ve ÖSS adı altında tek basamaklı bir sınav haline getirildiği 1999 yll, sınavın tekrar iki basamaklı olduğu 2010 yllı üniversiteye giriş sınavlarındaki değişikliklerin uygulandığ1 yılların sadece birkaçıdır (Temli Durmuş ve Kasa, 2015). 2017-2018 eğitim öğretim y1lı için ise adayların farklı bir sınav sisteminde yüksek öğretime geçecekleri tartsşmaları vardır. Sınavın ismi Yükseköğretim Kurumları Sınav1 (YKS) olarak değiştirilmesi planlanmış ve 40'ar Türkçe ve Matematik alanlarından çoktan seçmeli sorudan oluşan Temel Yeterlik Testi iki basamaklı sınavın ilk basamağını oluşturması planlanmıştır (ÖSYM, 2017). Ancak, Can’a (2017) göre; 2017 yllının Eylül ayında alınan ani bir kararla Yükseköğretim Kurumları Sınavı (YKS) getirilmesini üniversiteye giriş sınavlarının süresi, içeriği, değerlendirme biçiminin sıklıkla değiştirilmesi, zaten bireylerde olumsuz düşüncelere neden olan sinavlara yönelik tutumu ve görüşlerin çözümünde sağlıklı ve tutarlı bir eğitim planlamasının ve eğitim politikası yaklaşımlarının izlenmesi gerektiğini belirtmiştir.

Üniversiteye giriş sınavlarının ilk basamağı olan ÖSS'ye yönelik tutum okul türlerine göre incelendiğinde istatistiksel olarak anlamlı bir farklılık bulunamamıstır (Ekici, 2005). Tutumları arasında farklılık olmamasına rağmen okul türlerine göre ÖSS başarısı incelendiğinde fen lisesi öğrencilerinin üstün performans gösterdikleri ancak meslek liselerindeki başanının son derece düşük olduğu görülmektedir. Meslek liselerinin yıllara göre başarı yüzdeleri yıllara göre düşüş eğiliminde olduğu görülmektedir (Berberoğlu ve Kalender, 2005). Mesleki eğitimi daha cazip kılmak ve kayit yaptıran öğrenci sayısını arttırabilmek için 10 Temmuz 2001 tarih 24458 nolu Resmi Gazetede yayımlanan 4702 sayılı kanun gereğince belirli öncelikler tanımlanarak, meslek liselerinde aldıkları eğitime bağlı kalınarak öğrenciler sınavsız geçişle meslek yüksek okullarına kayıt yaptırabildiler (Yüksel ve Erkutlu, 2003). Bu kararın uygulanmasına rağmen Meslek liselerinde öğrenim görmekte olan öğrencilerin yükseköğrenimde istedikleri bölüme gidemedikleri, öğrenci başarısının yetersiz olduğu, kültür derslerinin az olduğu sıralanan sorunlar arasındadır (Demirtaş ve Küçük, 2008). 9 Aralık 2016 tarihli 6764 sayılı kanun ile sınavsız geçiş uygulamasına son verilmiştir. Böylece meslek yüksek okullarındaki doluluk oranı \%91,42'den \%62,55’e gerilemiştir (Can ve diğ, 2017). Lise sonrası mesleki eğitime bakıldığında meslekî ve teknik eğitim mezunlarının izlenememesi ve yeterli düzeyde istihdam edilememesi, ilkokul ve ortaokul yıllarında etkili bir mesleki rehberlik sunulamamasının mesleki eğitimde var olan soruları artırmaktadır (Can ve Doğan, 2014).

Meslekî ve teknik ortaöğretim iş ve meslek alanlarına iş gücü yetiştiren ve öğrencileri yükseköğretime hazırlayan öğretim kurumlarıdır. Meslekî ve teknik ortaöğretim; erkek teknik öğretim okulları, kı teknik öğretim okulları, ticaret ve turizm öğretimi okulları ve Din öğretimi okullarından oluşmaktadır (MEB, 2006). Günümüzde ticaret, sanayi ve hizmet sektöründe yetişmiş elemana duyulan ihtiyaç, yeterli bilgi, beceri ve uygulamayla yetişmiş ara elemanların önemini arttırmaktadır. Bunun için yüksek öğretim kurumlarının yeterliği ve sorunları büyük önem taşımakta (Alkan, Suiçmez, Aydınkal ve Şahin, 2014) meslek liselerinden mezun olup önkoşul öğrenmelerini tamamlamış bireylerin yüksek öğretime geçişlerinin desteklenmesi anahtar rol oynamaktadır. Meslek lisesi mezunlarının genel lise mezunlarına oranla daha az istihdam sıkıntısı çektikleri göz önüne alındığında ve ara eleman ihtiyacını karşılamak için lise düzeyinde meslek dersleriyle tanışan öğrencilerin üniversiteye giriş sınavında sınav kaygısını daha az yaşamaları beklenebilir (Temli Durmuş ve Kasa, 2015). 
Temli Durmuş, Y. (2017). Meslek lisesi 12. Sınıf öğrencilerinin üniversiteye giriș sınavı kaygıları ve beklentileri üzerine nitel bir çalısma. Journal of Human Sciences, 14(4), 4826-4837. doi:10.14687/jhs.v14i4.5148

\section{Problem Durumu}

Ortaöğretim kurumlarına geçerken öğrenciler sınav sonuçlarına göre kayıt yaptırmakta, yüksek puan alan öğrenciler öncelikle fen liselerinin ve sonrasında anadolu liselerini tercih etmektedirler. Akademik başarısı düşük olan öğrencilerin meslek liselerine gideceği alg1sı toplum içinde yaygındır. Meslek liselerinin kuruluş amacına bağlı olarak ara eleman yetiştirmek ve yüksek öğretim kurumlarına öğrenci yetiştirme hedefleri doğrultusunda öğrenci yetiştirilmektedir. Öğrencilerin sınava yönelik algıları ve kaygı durumlarını belirlemek, çözüm önerilerini almak güncellenen uygulamalar açısından büyük önem taşımaktadır.

\section{Amac}

Bu çalışmanın amacı, meslek lisesi 12. Sınıf öğrencilerinin üniversiteye giriş sınavına yönelik kaygılarını nitel bir çalışma ile nedenlerini ve çözüm önerini birlikte ortaya koyabilmektir.

\section{Yöntem}

Bu nitel çalışmada rahat ulaşılabilir örneklem yöntemi ile katılımcılara ulaşılmıştır. Var olan bir durumu olduğu gibi ortaya koymak için nitel araştırma yaklaşımı benimsenmiş ve yarı yapılandırılmış görüşme tekniği kullanılmıştır. Tarama çalışması olarak tasarlanan çalışmada yarı yapılandırılmış görüşme soruları, araştırmacı tarafindan hazırlanmış, farklı bir üniversitede görevli nitel çalışma alanında uzman Sınıf Eğitimi Anabilim Dalında görevli bir öğretim üyesinin işbirliği sağlanmıştır. Kodlar hakkında iki araştırmacı fikir birliği sağlayana kadar tartışmıştır.

Yar1-yapılandırılmış görüşme tekniğinde, araştırmacı sormayı planladığ1 soruları içeren görüşme formunu hazırlar. Yarı yapılandırılmış görüşme formunun en önemli özelliklerinden biri görüşmenin akışına bağlı olarak, değişik yan ya da alt sorularla görüşmenin akışını etkileyebilme ve görüşme yapılan kişinin yanıtlarında ayrıntılı bilgi edinebilme şansını araştırmacıya verebilmesidir (Türnüklü, 2000).

Çalışmanın ilk aşamasında tarama yönteminin uygulanmasına karar verilmiş ancak detaylı bilgi sağlayamaması nedeniyle tüm katılımcılarla yapılan bireysel görüşmelerle çalışmaya tekrar başlanmıştır. Bu nedenle sorular görüşme sorusu olarak düzenlenmiş ve somut örnekler istenerek, yarı yapılandırılmış görüşme formunun sağladığı avantajlar ile ayrıntılı bilgi elde edilebilmiştir.

\section{Calısma Grubu}

Çalışma grubuna iki farklı ilden toplam üç meslek lisesi dâhil olmuştur. İdarecilerinden izin alınarak gönüllü öğrencilerle görüşme yapılmıștır. Çalıșma grubuna katılan iki okuldan biri teknik ve endüstri meslek lisesi, diğer ise meslekî ve teknik anadolu lisesi olarak hizmet vermektedir.

Verilerin toplanması sırasında öğretmenler odası, psikolojik danışma ve rehberlik öğretmeninin ve müdür yardımcısının odası kullanılmıştır. Malatya ilinden 6 öğrenci, Manisa ilinden 24 meslek lisesi öğrencisi, toplam 30 onikinci sınıf öğrencisi çalışmaya gönüllü katılmıştır. Görüşmelerin bir kısmı ses kaydına alınmış ve önemli bir kısmı not alma tekniği kullanılarak döküman haline getirilmiştir. Katılımcıların 7’si kız öğrenci, 23’ü erkek öğrencidir.

\section{Verilerin Analizi}

Açık uçlu sorular yoluyla elde edilen nitel verilerin analizinde kodlamaya dayalı (tümevarımcı) analiz tekniğinden yararlanılmış, içerik analiz kullanılmıştır. Malatya'da iki araştırmacı tarafindan yapılan görüşmeler sonucu elde edilen ham verilerin kodlanmasında iki araştırmacı 6 katılımcının görüşlerini kodlar oluşturarak kategorilere ayırmış ve Manisa'da yapılan görüşmeler yazar tarafindan ve elde edilen veriler yapılmış ve nitel araștırma konusunda uzman bir başka araştırmacının kodlar hakkında görüşleri analiz sürecinde alınmıştır. Çalışmanın başında Malatya ve Manisa illerinde öğrenim görmekte olan meslek lisesi öğrencilerinin karşılaştırılması planlanmış, çalışmanın bulguları bir farklılık göstermediği için karşılaştırma yapılmamış ve bütüncül sonuçlar rapor edilmiştir. 
Temli Durmuş, Y. (2017). Meslek lisesi 12. Sınıf öğrencilerinin üniversiteye giriș sınavı kaygıları ve beklentileri üzerine nitel bir çalısma. Journal of Human Sciences, 14(4), 4826-4837. doi:10.14687/jhs.v14i4.5148

\section{Geçerlik ve Güvenirlik Çalışması}

$\mathrm{Bu}$ çalışmada iç geçerlik için çeşitleme ve katılımc1 teyidine gidilmiştir. Çeşitleme bu çalışmanın sonuçları için bir gereklilik olarak ortaya çıkmıstır. Görüşme bulguları psikolojik danışma ve rehberlik öğretmenlerinden de görüş almayı gerekli kılmış, okul idaresinin öğretmenlerin tamamına yönelik "öğrencilerden düşük beklenti" hakkındaki net verilerine ihtiyaç duyulmuş dolayısıyla çeşitleme yapılmıştır. Katulımcı teyidi için ise öğrencilerle odak grup görüşmesi yapılmıştır. Dış geçerlik için ise teyit incelemesi nitel araşturma konusunda uzman bir öğretim üyesi tarafindan yapılmıştur. Teyit incelemesi sırasında genel nedenler ve istekler olarak adlandırılmış kategoriler İlköğretim, Psikolojik Danışma ve Rehberlik Birimi ve İstekler olarak değiştirilmiştir.

\section{Bulgular}

Çalışmanın bulgularında tek bir tema altında birleşmiştir: Öğretmenlerin Etkisi. Kategoriler ise Üniversiteye Giriş Sınavları, İlköğretim, Psikolojik Danışma ve Rehberlik Birimleri ve İstekler olarak belirlenmiştir.

\begin{tabular}{rll}
\multicolumn{1}{l}{ Kategori } & Kodlar \\
\hline 1. Üniversiteye Giriş Sinavları & 1.1. Metaforlar \\
& & 1.2. Zaman Yönetimi \\
\hline 2. İlköğretim & 2.1. Temel bilgilerin olmaması \\
\hline 3. & Psikolojik Danışma ve Rehberlik Birimi & 3.1. Bireysel Psikolojik destek olmayış1 \\
& & 3.2. Ailelerin yüksek beklentisi \\
& 3.3. Öğretmenlerin düşük beklentisi \\
\hline 4. İstekler & 4.1. Süreçte bilinçlendirme \\
& 4.2. Genç öğretmenlerin olması \\
\hline
\end{tabular}

\section{1.Üniversiteye Giriş Sınavları}

Görüşmelerde, uzman görüşü doğrultusunda konuya giriş sorusu olarak eklenen 'YGS ve LYS sizin için ne ifade ediyor' sorusunun yanttları, öğrencilerin içinde bulundukları psikolojik duruma dikkat çekmektedir. Öğrenciler, üniversiteye giriş sınavlarının oluşturduğu duygu ve düşünceyi ifade etmek için çeşitli metaforlar kullanmışlardır. Öğrenciler bu sınavları, "savaş", "ölüm” ve "ahiret" metaforları ile açıklamayı tercih etmişlerdir. Ahiret metaforlarını açıklarken sınav sorularını "ahiret soruları" olarak tanımlamış, hayatın başlayabilmesi için bu sınavı başarıyla atlatılması gerektiği, sonrasında başka bir sınav olmaması ve huzuru bulmak ifadeleriyle açıklanmıştır. Sınava giren insan sayısının fazla olmasını "sınav günü okullara giden kalabalığın mahşer yerini anımsatması" ifadeleriyle açıklanmıştır. Ahiret metaforu altında açıklanan tek bir hedefe ulaşmaya çalışan kalabalığın varlığı tanımıla tutarlı bir şekilde "savaş" metaforu vurgulanmıştır. "Hayatımızın savaşı", ve "var olma savaşı" ifadeleri hayatta bir yerimizin olması için bu sınavda başarılı olmalıyı, toplumdaki yerimizi bu sınav belirleyecek gibi ifadelerle desteklenmiştir. Herhangi bir metaforla açıklamayı tercih etmeyen katıllmcılar zaman yönetiminde zorluk çektiklerini belirtmişlerdir. Sınava gireceklerinin bilincine son yıl ulaştıklarını ve bir yılda baş edebileceklerinden fazla içerikle yüz yüze geldiklerini belirtmişlerdir. İyi bir gelecek için üniversiteye giriş sınavlarında başarılı olmak bir zorunluluk olarak görülmekte, başarısızlık ihtimali hayatın bireyin elinden kayması olarak tanımlanmaktadır. Dört yıllık süreçte sınavların kapsamına dâhil olan bütün derslerin içeriklerini öğrenebilmek veya tekrar edebilmek için 1 yılllk sürecin sıkınto yarattı̆̆1 ve zaman yönetimi konusunda güçlük çektikleri vurgulanmış, gündelik uykuya ve yemeğe ayrılan zamanın bile psikolojik baskı oluşturduğu ifade edilmiştir.

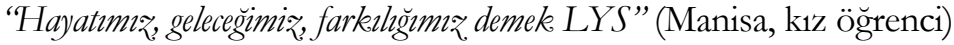

"Gercekten uykusuұluk, çevre baskess bayağz yoğun geçiyor, günde 5 saat uyuyabiliyorum. LYS YGS

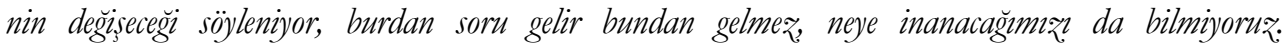

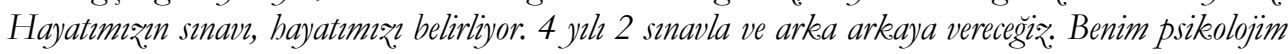
bozuldu; arkadaşlarma bakzyorum, ama ben yapamiyorum. Durumum bölle". (Malatya, erkek öğrenci) 
Temli Durmuş, Y. (2017). Meslek lisesi 12. Sınıf öğrencilerinin üniversiteye giriș sınavı kaygıları ve beklentileri üzerine nitel bir çalışma. Journal of Human Sciences, 14(4), 4826-4837. doi:10.14687/jhs.v14i4.5148

Bir katılımcı hayatı sınavla eşdeğer tutmuştur. Üniversiteye giriş sınavlarının öğrencide büyük stres yarattığı sınava yükledikleri anlamdan anlaşılmaktadır. Bu sınavın hayatta var olabilmek için başarıyla sonuçlandırmak gerektiğine inanan katılımcılar açıklamalarında ölüm, baskı, sisteme yönelik güvensizliklerini ifade etmektedir.

"Son seneye birakinca gerçekten zor oluyormus, bunu ögrendim ve şunu anladim okula elimde olsa bic gelmem, zaman kaybı. Okulun yardımı fazla değill” (Malatya, kız öğrenci).

"Tiki sinavla hayatımı̨n anlam belirlenecek. Uykum geliyor, uyumak istiyorum ama uyursam vicdan azabr çekiyorum. Uyumaynca ögrenemiyorum. Kendime kirap duruyorum niye yullarm boş geçirdim diye. Kendime ayırdiğm her dakika vicdan azabl. Arkadaşlarlarmla konusana kadar ne kadar soru çözerim, yemek sonrası ağırllk çökeünce bu₹ursu₹lanyorum pisman oluyorum” (Manisa, erkek öğrenci).

Öğrencilerin zaman yönetimi konusunda desteğe ihtiyacı olduğu öğrenci ifadelerinden anlaşılmaktadır. Günlük sağlıklı uyuma sürelerini bile vicdan azabı nedeni olarak tanımlamış ve uyuduğu zamanlar için gün içerisinde büyük pişmanlık duyduğunu belirtmiştir.

\section{2.İlköğretim}

Katılımcılar hem ilkokul hem de ortaokulda aldıkları bilgilerin kalıcı olmadığını, bugün yaşadıkları motivasyon eksikliğinin temelinde ilköğretim yıllarının yattığını belirtmişlerdir. Lise döneminde öğrenme-öğretme sürecinde edindikleri bilgilerin anlamlı gelmediğini, önkoşul bilgilerinin yetersiz olduğunu somut örnekler yoluyla aktarmışlardır. İlköğretim yıllarında başarılı olan arkadaşlarının şu an fen lisesi, anadolu lisesi gibi okul türlerinde eğitim gördüklerini, kendilerinin başarılı olamadıkları için meslek lisesinde eğitim gördüklerini belirtmişlerdir. Meslek lisesinde okumak katılımcılar için bir tercih değil bir mecburiyet olarak değerlendirilmiştir.

"Altyapr olması lazım, bu da ilkokulda olussturuluyor bence" (Manisa, kız öğrenci).

"Şimdi, benim dersi anlayabilmem için baz? seyleri bilmem lazum. Normalde 1 saat YGS çalssyorsam 2 saat LYS çahsmam lazum. Ama ben temelimi olusturmaya çalssyorum. Dersten yüksek not almak da umrumda değildi bu ynla kadar. YGS daba gok vaktimi alyor bu sefer" (Manisa Erkek öğrenci).

"Ögrenciler de çok tembel. Calssmak istemiyorlar. Calssmayn burakan burakizor. Zor geliyor, birikmiss, bas edemiyor o kadar konuyla. Yani biz, aslinda YGS'ye çalssyoruz, temel sağhyoruz, seneye de LYS'ye çalssacağrz. temelimizi sağlamıs olacă̆rz. Başarssı olduk ki daba önce șimdi meslek lisesindeyiz" (Malatya, kız öğrenci).

Veriler temel bilgi yetersizliğini ortaya koymaktadır. İlkokul ve ortaokulda verilen bilgilerin yetersiz olması ya da kalıcı öğrenmenin sağlanamış olması bir düşünce olarak ortaya konmuş, geçerli bir veri olup olmadığını anlayabilmek için öğretmen teyidine başvurulmuştur. Edebiyat ve Matematik öğretmenlerinin sözel ve sayısal alanda temel dersleri veren öğretmenler olarak görüşleri alınmıştur.

"Daha adin soyadin düzgün yazamyyor cocuk. Siz̨e bir göstersem sinav kâğgtlarm okuma yażma ögretin önce hocam dersini . Dilbilgisi kurallarndan bibaber. İstediğin kadar anlat, çocuk daha "l" ile " $n$ " yi ayrd edemiyor, -de -da yn ayr yasmast gerektigizini bilmiyor" (12 yl deneyimli kadın Türk Dili ve Edebiyatı öğretmeni, Manisa).

"Carpım tablosunu bilmiyorlar. Benden beklenen ile ögrenci durumu arasunda ucurum var. Meslek dersleri zaten ön planda kïltür dersleri ikinci planda" (13 yil deneyimli erkek Matematik Öğretmeni, Manisa).

Üçleme için başvurulan Türk Dili ve Edebiyatı ve Matematik öğretmenleri lise eğitim programlarındaki kazanımları sağlayabilmek için öğrencilerin ön koşul bilgilerinin yetersiz olduğunu belirtmişlerdir. $\mathrm{Bu}$ durum öğrenci görüşleri ile öğrenci görüşlerinin tutarlı olduğunu ortaya koymaktadır. Okul idaresi de öğrencilerin motivasyonsuz olmasının altını çizmiştir. Davranış problemi yaşadıklarını belirtmişler ancak akademik başarı sağlayabilmek için baş etmeleri gereken çok fazla etken olduğunu belirtmişler, aile duyarsızlığı, çeteleşme, her şeyi kolayca elde etmenin verdiği rahatlığın öğrencilerin motivasyonsuz olmalarının nedenleri olarak sıralanmıştır. 
Temli Durmuş, Y. (2017). Meslek lisesi 12. Sınıf öğrencilerinin üniversiteye giriş sınavı kaygıları ve beklentileri üzerine nitel bir çalısma. Journal of Human Sciences, 14(4), 4826-4837. doi:10.14687/jhs.v14i4.5148

\subsection{Psikolojik Danı̧̧ma ve Rehberlik Birimi}

Bu çalışmada en yüksek frekansla vurgulanan beklenti psikolojik danışma ve rehberlik (pdr) birimine yönelik olmuştur. Katılımcılar sadece kişisel rehberlik değil, mesleki rehberlik, eğitsel rehberlik, anne-baba eğitimi konusunda da pdr öğretmenlerinden destek beklemekte, bilinçlendirmeye yönelik hizmetin sadece son sınıfta değil süreç içinde yapılmasını beklemektedir.

"Ben ölsem bile ailem 2 gün sonra yemek. yemeğe baslayacak. Sağhl̆ğn daha önemli olduğunu anlatamyorum aileme, olan bana olacak." (Malatya, kı öğrenci).

Rehberliğin yanı sıra 12. sınıf öğrencileri psikolojik destek de beklemektedir. Uykusuzluk, aile baskısı, suçluluk duygusu gibi duygular hissettiklerini belirten öğrenciler, bu süreçte bilinçli olsalardı bu kaygı verici duyguların sınav zamanı yaklaştı̆̆ında ortaya çıkmacağını belirtmişlerdir. $\mathrm{Bu}$ hislerle baş edemediklerini, bunun da yılgınllğg ve ümitsizliğe yok açtığı belirtilmiştir.

"Ben cok buzursuzum. Rebberlikeciyle konusamyorum bile. Beni kimse dinlemiyor, anlamyor ama suçluyor" (Manisa, erkek öğrenci)

"Bir de hocam tereddüt ediyoru₹, ya basaramąsam korkusu var. Ben bir rebberlik hocası olsam okulumu görevli olduğum şehirde üniversite varsa, ïniversiteye götürürüm, ne kadar çalşmışlar, liseden farkh olarak ne yapmuslar, kazanamasaydo ne olurdu ne bissederdi, bu tür seylerle, siz de yapabilirsiniz dese, $O$ da mutlake zorluk gekmistir, anlar bizi. Haftada 1 sinemaya git dese destek. sağlar. Ailelerin destek olması lazım" (Malatya, erkek öğrenci)

Aile eğitimine yönelik beklenti içinde olan kattlımcıların bu fikirleri uzmana sorulmuştur. Aileleri bilinçlendirmek için psikolojik danışmanların toplantı yapması konusunda psikolojik danışma ve rehberlik öğretmeni şu ifadeyi kullanmıştır:

"Veli toplantısna bile gelmeyen veli benim bilgilendirme toplantuma mo gelecek? Baz? velilerimiz, șehir dışında yaşzyor. Veliler ilgili olsa neden iletişim kurmayalim? Bir iki defa çağırdim, çok az kathlim oldu. Rehberlikegi çok basarle diye ismimi duyurdular săg olsunlar ama sonra çağgrdğğmda gelmediler" (7 yil deneyimli erkek PDR öğretmeni, Manisa).

Aile okul işbirliği konusunda psikolojik danışmanlardan beklentiler açık ve net bir şekilde belirtilmiştir. Bu sorumluluğu kabul eden psikolojik danışmanlık ve rehberlik (pdr) öğretmeni talep edilmesinin, bu ihtiyacın dile getirilmesinin doğruluğunu vurgulamış, ancak gönüllü katılımın olmayacağını eski deneyimlerine atıfta bulunarak açıklamıştır.

Her iki okulda da bir pdr öğretmeni görev yapmakta ve zaman sıkıntısı çketiklerini belirterek ailelerin bilinçli olmadığının altını çizmişlerdir.

Katıllımcılar öğretmenlerin kendilerinden başarı beklememesinin, başarısız olacaklarına ikna edilmelerinin üzüntüsünü dile getirmişlerdir. Öğretmenlerinin hem tavır olarak öğrencileri aşağıladıklarını hem de kendilerine olan güvenlerini yok etmeye çalıştıklarını düşünmektedir. Öğretmenlerin öğrencilerin konuları anlama yeterliliğinin olmadığını düşündüklerini, bunu her fırsatta aşağılayarak belli ettikleri vurgulanmıstır.

"Ben dersimi anlatayum, anlamayandan banane. Rebberlik hocası da destek olmuyor, meslek lisesiniz.

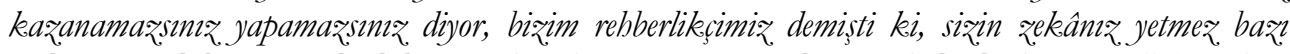
seylere. Yapabilirsiniz, çalssabilirsiniz demedi. Diğer ögrretmenlerimiz de böyle davraniyor" (Manisa, kız öğrenci).

"Öğretmen konusunu anlatyor çlezyor, soru soramiyoruz, teneffiiste sormak istiyoruz, simdi sirasi değil diyorlar, yarn sor diyorlar, ilgilenmiyorlar. Bu smuftan üniversiteyi kazanan bir iki kisisi ancak çıar, basaramazsmı deniyor ve arthe bundan zeve aldklarm düsï̈nïyorum. Niye olumlu bakmiyorlar, bakem bir şeyler yapyyoruz, destek, olun, ama onlar köstek oluyorlar" (Malatya, kız öğrenci).

Olumlu olan her görüşe her paylaşıma açık olduklanını belirten katılımcılar, özellikle onlanı anlayan bireylere ihtiyaç duyduklarını dile getirmişlerdir. Bunun kendileri gibi meslek lisesinden gelip başarılı olmuş bireylerin katıldığı seminerler düzenlenmesinin, paylaşımda bulunma yolunun açılmasının etkili olacağı vurgulanmıştır.

Öğretmenlerin düşük beklentisine ailelerin yüksek beklentisi eşlik etmektedir. Ailelerin gerçekçi beklenti içinde olmadıklan, maddi olarak çok büyük fedakarlığa girdikleri, bu durumun da öğrencilerde kayg1 yarattı̆̆ı belirtilmiştir. 
Temli Durmuş, Y. (2017). Meslek lisesi 12. Sınıf öğrencilerinin üniversiteye giriș sınavı kaygıları ve beklentileri üzerine nitel bir çalısma. Journal of Human Sciences, 14(4), 4826-4837. doi:10.14687/jhs.v14i4.5148

\begin{abstract}
"Ailemin benden beklentisi çok yükesek. Çalşsısam olacağın söylïyor, maddi manevi ellerinden geleni yapıyorlar. Bunun karşsllğın verememek beni korkutuyor. Onlar ǚmek, istemiyorum” (Manisa, kız öğrenci).
\end{abstract}

\title{
8.4. İstekler
}

Öğretmenlerin genç olması, katılımcılar için iletişim kurabilecekleri, onları anlayabilecek, rahatça konuşup danışabilecekleri bireyler anlamına gelmektedir. Yaş almış öğretmen ise, pasifleşmiş, yıllardır değişikliğe uyum sağlama gereği duymamış öğretmen olarak tanımlanmaktadır. Dershanede daha başarılı olduklarının nedeni de, ordaki öğretmenlerin daha genç ve ilgili olmaları. Okullarda görev yapan öğretmenler ise öğrenciye emek vermek konusunda ciddi direnç gösterdikleri, öğrenciyi değersiz gördükleri konusunda eleştirilmişlerdir.

"Sabah günaydn diyoruz hocalarmuza yant vermiyorlar bile. Görevlerini iyi yapmak gibi bir istekleri yok. Nasllsa maaslarm alyorlar, ister işini yap ister yapma. Genc ögrretmenler güleryüzlü oluyor, konusabiliyorsun, seni aşağglamiyor. Biz. merkez, okuluz ya, bütün ögretmenlerimiz yașh" (Malatya, erkek öğrenci).

"Özel okul basararl ögrenciyi kapiyor, 14 kişilik, okul para almyyor ondan, hepsi burslu olan ögrencilerden bir simfi var. Yazın bile eğitim veriyorlar gizli gizlli. 700 lira maas da veriyorlar bu ögrencilere. Burslu SBS den sonra, parasyla gidenden bir beklentileri yok, ögrenciler çalsmazsa özel okul sana bir şey yapamaz ki. Ama 14 kişilik simftakiler derece yapyyor. SBS den başlyormus iş̧".

(Manisa, erkek öğrenci).

Katıllmcıların bir başka beklentisi süreçte bilinçlendirme, son sınıfa gelmeden süreç içerisinde üniversiteye giriş sınavlarının tanıtılması, düzenli ders çalışma alışkanlığı kazanılmasına yönelik destek, zaman yönetimi, velilerin gerçekçi beklenti geliştirmesine yönelik destek verme katılımcıların istekleri arasındadır. Bunların da liseye başlanılan ilk günden itibaren düzenli yapılmasının etkili olacağı düşünülmektedir.

Öğretmenler, başarıya ulaşmak için süreci iyi değerlendiremeyen öğrencilerin, son bir yılda bütün eğitim öğretim hayatlarına ait bilgileri edinilebilmesi için uğraştı̆̆ını ve analiz sentez yeteneğini geliştirilmesinin bir yıla sığamayacak kadar kapsamlı olduğu görüşündedir. Öğrenci ise bu açıkları kapatmak için zaman yaratmaya çalışmaktadır. Vazgeçmek istediği ilk ley ise okula ayırmak zorunda olduğu günlük zamandır.

\section{Tartışma}

$\mathrm{Bu}$ çalışmada elde edilen bulgular üniversiteye giriş sınavlarının ölüm, mahşer yeri gibi olumsuz metaforlarla anlatılmıştır. Ölümden bahsetmeleri, ailelerin sağlık olsun diyerek esnek bir tutum içerisinde olmayışlarının öğrencilerin yaşadığa kaygıya yönelik önemli bulgulardır. Zayıf sosyal destek, düşük öz-sayg1 ve yetersiz sorun çözme becerisi ergenlik dönemi depresyonu için risk faktörleri olarak tanımlanmaktadır (Eskin, Ertekin, Harlak ve Dereboy, 2008). Sosyal destek konusunda arkadaşlık ilişkilerinden hiçbir katılımc1 söz etmemiştir. Katılımcıların "ahiret" metaforunda üniversiteye giriş sınavına giren kişilerin sayıca fazlalığının altı çizilmiş ancak sosyal destek, arkadaşlarla iletişim konularına hiç değinilmemiştir. 12. sınıf öğrencileri için sınava yönelik içeriğin derste ve zamanında öğrenilmediği için son sınıfta zaman yönetimi açısından sıkıntı çektiklerini göstermektedir. Zaman yönetimi yüksek olan öğrencilerin akademik başarısı da yüksektir (Demirtaş ve Özer, 2007).

İlköğretimden temel bilgi sahibi olarak gelmememeleri çalışmanın ikinci kategori ve kodudur. Üçleme sonucu öğrencilerin yeni konular için hazırbulunuşluklarının olmadığına dair öğretmen görüşlerine ulaşllmıştır. Benzer bir şekilde, Demir ve Demir’in (2012) yaptı̆̆1 bir çalışmada farklı okul türlerinde görev yapan öğretmenlerin eğitim programlarını uygularken karşlaştıkları sorunlardan birinin hazırbulunuşluk düzeyi düşük öğrenciler olduğunu ortaya koymuştur. 
Temli Durmuş, Y. (2017). Meslek lisesi 12. Sınıf öğrencilerinin üniversiteye giriş sınavı kaygıları ve beklentileri üzerine nitel bir çalısma. Journal of Human Sciences, 14(4), 4826-4837. doi:10.14687/jhs.v14i4.5148

Bir diğer bulgu ise Psikolojik Danışmanlık ve Rehberlik kategorisi altında vurgulanan bireysel psikolojik destek olmayışı, ailelerin yüksek beklentisi ve öğretmenlerin düşük beklentisidir. Katılımcılar, öğretmenler tarafindan aşağılandıklarını düşünmektedir. Öğrenciden yüksek beklenti okul başarısının da yükselmesi ile sonuçlanmaktadır (Cotton, 1989). Bu doğrultuda öğrencilerden düşük beklenti öğrenci başarısızlı̆̆ını açıklayan faktörlerden biri olarak değerlendirilebilir. Benzer bir şekilde Yıldırım'ın (2000) yaptı̆̆ çalışmanın sonuçları öğretmen desteğinin öğrencinin akademik başarısını olumlu yönde etkilediği ortaya konulmuştur. Toplum içinde "günah keçisi" ilan edildiklerini belirten öğretmenlerin motivasyon kaybı (Temli Durmuş ve Kasa, 2015) öğrencilerine yönelik beklentilerini de etkilemiş olması beklenir. Aile desteği de öğrencilerin akademik başarısını arttıran etkenlerden biridir (Yıldırım, 2000). Bulgular öğrencilerin aile desteğinden yoksun olduklarını ancak ailenin yüksek beklentisinin kaygı verici olduğunu ortaya koymuştur. Öğretmen desteği de sağlanamamaktadır. Bu iki değişkenin akademik başarı üstüne olumsuz etkisinden bahsedilebilir. Öğretmenler aile ile işbirliğine gitmek isteseler bile ailelerin duyarsızlı̆̆ının umutsuzluğa neden olduğu belirlenmiştir.

Psikolojik Danışma ve Rehberlik öğretmenlerinden mesleki rehberliğin yanı sıra aile eğitimine yönelik destek de beklenmekte, uykusuzluk, suçluluk duygusu gibi psikolojik durumlar için de destek beklenmektedir. Balc1 (1992) meslek liselerinde görev yapan öğrenci, öğretmen ve okul idarecilerinin katılımcı olarak belirlendiği araştırmasında katılımcıların pdr biriminden beklentilerinin farklılık gösterdiğini ortaya koymuştur. Katılımcılar arasında takım çalışması yapmanın zor olduğu çalışmanın bulguları arasındadır. Bu çalışmada öğrenci, aile ve pdr biriminin birlikte çalışmasının öneminin altını çizmiştir. Peker ve Kaygusuz (2009) tarafindan yapılan bir çalışmada genel lise ve meslek lisesi öğrencilerinin psikolojik danışmanlık ve rehberlik biriminden beklentileri arasında istatistiksel olarak farklılık olduğunu belirlemiştir. Genel lise öğrencilerin beklentilerinin meslek liselerinde öğrenim görmekte olan öğrencilerden istatistiksel olarak anlamlı bir farkla daha fazla beklenti içinde oldukları saptanmıştır. Bu çalışmada ise sadece meslek lisesi 12. sınıf öğrencilerinin oluşturduğu çalışma grubunda anahtar rolde pdr öğretmenlerinin olduğu, aileye yönelik psikososyal eğitim programlarının uygulanmasına yönelik beklentileri vurgulanmıştır.

Sonuçlar meslek lisesi 12. Sınıf öğrencilerinin süreçte bilinçlendirme talep ettiklerini ve genç öğretmenlerin görev almasını istediklerini göstermektedir. Benzer bir şekilde Can ve Doğan'ın (2014) çalısması da ilkokul ve ortaokul yıllarında mesleki rehberliğin önemini vurgulamakta ve bu bilinçlendirmenin erken yaşlarda yapılmasının öneminin altını çizmektedir. Genç öğretmenlerin varlığ1 ise rahat iletişim kurabilecekleri, onlanı anlayabilen bireylerin olmasının güven vereceği düşüncesidir.

Tansel'in (1999) araştırmasına göre lise mezunlanı arasında istihdam yüzdelerine bakıldığında meslek lisesi mezunları genel lise mezunlarına göre yaklaşık yüzdelik oranda iki katı fazla istihdam edilmektedir. Katılımcıların hayatlarına devam edebilmeleri için üniversiteye giriş sınavlarında başarılı olmanın şart olduğunu düşünmektedir. Toplumsal statüye atıfta bulunarak meslek lisesinden mezun olup çalışmanın olumsuz bir durum olduğu belirtilmiştir. Üniversite öğrencileri arasında yapılan bir araşturma sonuçları "mezun olunca iş bulma kolaylı̆̆g"nın en önemli iki etkenden biri olduğunu ortaya koymuştur (Şahin, Zoraloğlu ve Firat, 2011). Meslek lisesi öğrencilerinin sosyal statüyü önemseyerek meslek liselerinin ana amaçlarından biri olan ara eleman yetiştirmeyi başka bir amaç olan "yüksek öğretim kurumlanı için öğrenciyi hazırlamak"tan daha az önemli olduğu sonucuna varilabilir.

Gelecek çalışmalarda fen liseleri, anadolu liseleri ve meslek liseleri arasında üniversiteye giriş sınavlarındaki kaygı nedenleri ve baş etme yöntemlerine yönelik araştırmalar önerilebilir. Ailenin beklentileri, öğrencinin beklentileri ve pdr öğretmenlerinin deneyimleri konusunda detaylı bilgi sağlanabilecek nitel çalışmalar yapılabilir.

\section{Kaynakça}


Temli Durmuş, Y. (2017). Meslek lisesi 12. Sınıf öğrencilerinin üniversiteye giriş sınavı kaygıları ve beklentileri üzerine nitel bir çalısma. Journal of Human Sciences, 14(4), 4826-4837. doi:10.14687/jhs.v14i4.5148

Alkan, R. M., Suiçmez, M., Aydınkal, M. ve Şahin, M. (2014). Meslek yüksekokullarındaki mevcut durum: Sorunlar ve bazı çözüm önerileri. Yükseköğretim ve Bilim Dergisi, 4(3), 04 Aralık 2017 tarihinde https://www.researchgate.net/profile/Menekse Sahin/publication/286192736 Current Situation in Vocational Schools Issues and Some Suggested Solutions/links/57db18bc08ae5292a37699fe. pdf adresinden alınmıștır.

Balc1, S. (1992). meslek liselerinde psikolojik danısma ve rehberlik hizmetlerinden beklentiler. Ondokuz Mayıs Üniversitesi Eğitim Fakültesi Dergisi, 4 Aralık 2017 tarihinde file:///C:/Users/ymd/Downloads/5000114206-5000169184-1-SM.pdf adresinden alınmıştır.

Baştürk, S. (2011). Üniversiteye giriş sinavına hazırlanma sürecinin öğrencilerin Matematik öğrenmeleri üzerine olumsuz yansımaları. Hacettepe Üniversitesi Ë̆itim Fakültesi Dergisi, 40, 69-79.

$\begin{array}{lllll}\text { Baybuğa, } & \text { E. } & \text { (2013).Sınav } & \text { Kaygisı. } & \text { tarihinde }\end{array}$ http://www.tavsiyeediyorum.com/makale_10595.htm adresinden alınmıştır.

Berberoğlu, G. ve Kalender, İ. (2005). Öğrenci başarısının yllara, okul türlerine, bölgelere göre incelenmesi. Eğitim Bilimleri ve Uygulama Dergisi, 4(7), 07.12.2017 tarihinde https://s3.amazonaws.com/academia.edu.documents/37834801/PISA OSS.pdf?AWSAccessKeyI $\underline{\mathrm{d}=\text { AKIAIWOWYYGZ2Y53UL3A\&Expires }=1512646147 \& \text { Signature }=2 \mathrm{DCCuB} 54 Y D 1 \% 2 \mathrm{BXYqB}}$ fvKBdZt26CU\%3D\&response-content-

disposition=inline $\% 3 \mathrm{~B} \% 20$ filename $\% 3 \mathrm{DOgrenci}$ Basarisinin Yillara Okul Turleri.pdf adresinden alınmıştır.

Can, E. (2017). Öğrenci görüşlerine göre merkezî sınavların etkilerinin belirlenmesi. The Journal of Academic $\begin{array}{llllll}\text { Social } & \text { Science, } & 58 & 27 & \text { Aralk } & 2017\end{array}$ http://www.asosjournal.com/Makaleler/1956689759 12842\%20Ertu\%C4\%9F\%20CAN.pdf

Can, E., Çiçek, H., Aktaş, F. O., Işik, T., Kasap, B. B., Tezsezer, S. ve Arpacıŏglu, I.T. (2017). Meslek yüksekokulu mezunlarının meslekî eğitimlerini değerlendirmeleri, Sosyal Bilimler Dergisi, 15, 28. Aralık 2017 tarihinde http://www.sobider.com/Makaleler/934720541 3726\%20Ertu\%C4\%9F\%20CAN.pdf adresinden alınmıştır.

Can, E. (2010).Türk eğitim sisteminde merkezî sınavların yeri. 19. Ulusal Eğitim Bilimleri Kurultayı. Uluslararası Kıbrıs Üniversitesi Eğitim Fakültesi. 16-18 Eylül 2010, Lefkoşa-KKTC. http://www.pegem.net/akademi/kongrebildiri detay.aspx?id=122786.

Can, E. ve Doğan, N.(2014).Meslekî ve teknik eğitim: Sorunlar ve öneriler. 23.Ulusal Eğitim Bilimleri Kongresi. Bildiri özetleri kitabı, 266. Kocaeli Üniversitesi Eğitim Fakültesi, 4-6 Eylül 2014, Kocaeli.

Cotton, K. (1989). Expectations and students outcomes. School improvement research series, 7, retrieved 12.22.2017 from http://educationnorthwest.org/sites/default/files/expectations-and-studentoutcomes.pdf

Dağlı, S. (2006). Özel dershanelere öğrenci gönderen velilerin dershaneler hakkındaki görüș ve beklentileriKahramanmaraş örneği. Yayınlanmamış Yüksek Lisans Tezi, Sütçü İmam Üniversitesi, Kahramanmaras.

Demirtaş, B. ve Küçük, M. (2008). Kız meslek liselerinin günümüzdeki sorunlarına yönelik öğretmen görüşleri. Ahi Evran Üniversitesi Kirşehir Eğitim Fakültesi Dergisi, 9(3), 21.08 .2017 tarihinde http://dergipark.gov.tr/download/article-file/15608 adresinden alınmıstır.

Demirtaş, H. ve Özer, N. (2007). Öğretmen adaylarının zaman yönetimi becerileri ile akademik başarısı arasındaki ilişkisi. Eğitimde Politika Analizleri ve Stratejik Araştırma Dergisi, 2(1), 10 Aralık 2017 tarihinde http://www.inased.org/epasad/c2s1/demirtasozer.pdf adresinden alınmıştır.

Ekici, G. (2005). Lise öğrencilerinin öğrenci seçme sınavına (ÖSS) yönelik tutumlarının bazı değişkenler açısından incelenmesi. Hacettepe Üniversitesi Eüitim Fakültesi Dergisi, 28, 06.11 .2017 tarihinde http://dergipark.ulakbim.gov.tr/hunefd/article/viewFile/5000048643/5000045963 adresinden tarihinde alınmıştır.

Eskin, M., Ertekin, K., Harlak, H. ve Dereboy, Ç. (2008). Lise öğrencisi ergenlerde depresyonun yaygınlığ ve ilişkili olduğu etmenler. Türk Psikiyatri Dergisi, 19(4), 2 Aralık 2017 tarihinde http://turkpsikiyatri.com/C19S4/382-389.pdf adresinden alınmıştır.

Jindal-Snape, D. \& Miller, D. J. (2008). A challenge of living? Understanding the psycho-social process of the child during primary-secondary transition through resilience and self-esteem theories. Education $\begin{array}{llllll}\text { Psychological Review, 20, } 217-236 . & 18 & \text { Aralk } 2017 \text { tarihinde }\end{array}$ https://link.springer.com/content/pdf/10.1007\%2Fs10648-008-9074-7.pdf adresinden alınmıştır. 
Temli Durmuş, Y. (2017). Meslek lisesi 12. Sınıf öğrencilerinin üniversiteye giriș sınavı kaygıları ve beklentileri üzerine nitel bir çalışma. Journal of Human Sciences, 14(4), 4826-4837. doi:10.14687/jhs.v14i4.5148

Lapan, R. T., Gysbers, N. C. \& Petroski, G. F. (2001). Helping seventh graders be safe and successful: a statewide study of the impact of comprehensive guidance and counseling programs. Journal of Counseling and Development, 79(3), 320-330. 18 Aralı 2017 tarihinde http://onlinelibrary.wiley.com/doi/10.1002/j.1556-6676.2001.tb01977.x/full adresinden alınmıştır.

Peker, A. ve Kaygusuz, C. (2009). Genel ve meslek liselerindeki öğrenci, öğretmen ve yöneticilerin psikolojik danışma ve rehberlik hizmetlerinden beklenti düzeylerinin incelenmesi. Sakarya Üniversitesi Eğitim $\begin{array}{lllllll}\text { Fakültesi } & \text { Dergisi, } & 17 & 4 & \text { Aralk } & 2017 & \text { tarihinde }\end{array}$ http://dergipark.ulakbim.gov.tr/sakaefd/article/viewFile/5000003801/5000004313 adresinden alınmıştır.

Şahin, H., Günay, T ve Bat, H. (2006). İzmir ili Bornova ilçesi lise son sınıf öğrencilerinde üniversiteye giriş sinavi kaygisi. STED, 15(6), 6.10 .2016 tarihinde http://www.ttb.org.tr/STED/2006/haziran/izmir.pdf adresinden alınmıştır.

Şahin, İ., Zoraloğlu, Y.R. ve Şahin Fırat, N. (2011). Üniversite öğrencilerinin yaşam amaçlant, eğitsel hedefleri, üniversite öğreniminden beklentileri ve memnuniyet durumları. Kuram ve Uygulamada Eğitim Yönetimi, 14 Aralık 2017 tarihinde http://kuey.net/index.php/kuey/article/view/923 adresinden alınmıştır.

Tansel, A. (1999). General versus vocational high schools and labor market outcomes in Turkey. Retrieved 12.22. 2017 from https://papers.ssrn.com/sol3/papers.cfm?abstract id $=263276$

Temli-Durmuş, Y. ve Kasa, B. (2015). School principles and teachers' evaluations on the reasons decrease in University Entrance Exams. Journal of Educational Sciences Research, 5(1), 165-190.

Yıldırım, İ. (2000). Akademik başarının yordayıcısı olarak yalnızlık, sınav kaygısı ve sosyal destek. Hacettepe Üniversitesi Ĕ̈itim Fakültesi Dergisi, 18, 22.12.2017 tarihinde file:///C:/Users/ymd/Downloads/5000048947-5000066418-1-PB.pdf adresinden alınmıştır.

Yolcu, M. A. (2015). Aile sosyo-ekonomik durumu ve ana-baba tutumlarının sınav kaygısı düzeyleri üzerine etkilerinin incelenmesi: Konya örneğinde üniversite sinavına dershaneye giderek hazırlanan öğrencilere bir $\quad$ uygulama. $\quad 06.10 .2017 \quad$ tarihinde http://acikerisim.selcuk.edu.tr:8080/xmlui/bitstream/handle/123456789/3731/391895.pdf?sequen $\mathrm{ce}=1$ \&is Allowed $\mathrm{E}_{\mathrm{y}}$ adresinden alınmıştır.

Yüksel, Ö. ve Erkutlu, H. (2003). Personeli güçlendirme-Empowerment. Gaæi Üniversitesi İktisadi İdari Bilimler Fakeillesi Dergisi, $5(1), \quad 11 \quad$ Aralı 2017 tarihinde http://iibfdergisi.gazi.edu.tr/index.php/iibfdergisi/article/view/324 adresinden alınmıştır.

\section{Introduction}

\section{Extended English Abstract}

The era we live in is called as "exam era" by educators (Baybuğa, 2013). Exams psychologically, physically, emotionally affect people's lives (Yolcu, 2015). In the historical perspective different applications were experienced to enter universities. High expectations on exam's score, family's high expectations that above a student' cognitive talents, ineffective study styles and fear of being connected between IQ level of a student with the exam's score lead to anxiety. University entrance exams are perceived as the final exams in adolescence's life, which is the most important predictor of one's profession. University entrance exams consist of 2 steps in Turkey. The content of the first stage is mainly composed of $9^{\text {th }}$ and $10^{\text {th }}$ grade content. The advanced level contents are covered by the second stage of the exams. When the exams results examined Science High Schools were established for training students who have high academic success as scientists. The perceptions of people vocational high schools are selected by the unmotivated students (Temli Durmuş ve Kasa, 2015). The students who take the university entrance exams perceived exams as crossroads in their lives and the young person adopt negative attitudes towards exams (Ekici, 2005).

\section{Purpose}

The aim of the study is to determine vocational high school $12^{\text {th }}$ grade students' anxieties and the reasons of anxieties and their suggestions to solve the problematic issues.

\section{Participants}

The participants are 30 vocational high school students in two cities. Six students are from 
Temli Durmuş, Y. (2017). Meslek lisesi 12. Sınıf öğrencilerinin üniversiteye giriș sınavı kaygıları ve beklentileri üzerine nitel bir çalışma. Journal of Human Sciences, 14(4), 4826-4837. doi:10.14687/jhs.v14i4.5148

Malatya and the rest 24 students are from Manisa and all of the participants enrolled in vocational high schools. Some school administers did not allow the researcher to use tape recorder. Therefore, note-taking technique is mostly used. Seven participants are girls and 24 participants are boys.

\section{Method}

Semi structured interview question form was developed and expert opinions were provided. Based on expert opinion the general views of students on university entrance exams were added to form to be able to reflect the general views. Tape recorders can be used in some interviews and mostly note taking technique was used because of the permission of the school administration. During the interview process and data analysis process two researchers who are experts in qualitative research helped to researcher. Content analysis was applied based on the codes emerged from the data set. Inductive approach was used.

\section{Results}

The results show one theme: Teachers' effect that underlines the expectations from teachers. Especially expectations from school counselor are highly remarkable. Four categories under the theme were named as University entrance exams, Elementary school, Counseling, and Demands. Codes for first category are metaphors and time management. Day of judgment and war are metaphors of students for university entrance exams. Time management is a vital issue for participants because they recognize they will enter the university entrance exams and they have to cover all of the content during their educational life. So, it creates stress and anxiety. The second category is Elementary School and it includes only one code that "Lack of pre-requisite learning". As a part of triangulation was provided and literacy teachers underline that the students cannot distinguish "l" sounds from " $n$ " sounds and curriculum demands attainments of in-detailed literacy information for students. The third category is named as Counseling Unit and it has three codes: Lack of psychological support, High expectations of families, and low expectations of teachers. The participants demanded various services from the counseling unit. The data showed that the participants have low self-esteem and they feel guilty because they have not studied in time. On the one side families have high expectations from students on the other side teachers have very low expectations from students. Teachers do not believe they can take high scores in the exams. The participants underlined that teachers persuade them they are lazy and unsuccessful; they cannot be successful in the exams. The fourth category is Demands: Giving information in the high school education process, and Needs for younger teachers. Different research findings show that the last year of the high school education, people recognize the importance of guidance; especially vocational guidance but readiness for the exams requires a process. The participants stress that nobody stimulate them to study. They demand for younger teachers; it means they can communicate with young teachers who can accept them and listen to them. According to participants aged teachers have high burnout level and they do not love and understand them. In order to provide triangulation counseling teachers' views was demanded. The participants demands for family psycho-education programs to make them realistic on expectations from their children. The teacher indicated that families do not participate in the family meeting to talk about their children's success in school. They probably would not attend the counseling program with students. School principle and mathematics teachers underline the lack of pre-requisite learning of the students and behavioral disorders of students.

\section{Suggestions}

The suggestions for further studies is to conduct projects to compare Science high school, Anatolian high school and Vocational high school students' perceptions of university entrance exams and anxiety levels. The reasons for the exam anxiety are suggested to study in further research projects. 